\title{
As ideias se esvoaçavam em meio à sua marcha: o Brasil submetido à “intuição crítica moderna” de Sílvio Romero (1865-1885)
}

\author{
Elton Flaubert de Figueredo*
}

\begin{abstract}
Resumo: No ocaso do Império, um jovem intelectual, Sílvio Romero, pretendia interpretar o país - e sua formação - a partir das novas vogas filosóficas vindas da Europa (positivismo, evolucionismo, etc.), a que ele identificava de "intuição crítica moderna". Entusiasmado com a Segunda Revolução Industrial e com as ideologias do progresso que vinham de fora, Romero advogava a inexistência de universais. Toda época tinha sua verdade relativa, e ela iria se sucedendo evolutivamente em direção ao progresso. Ele interpretava a formação do país a partir de um tripé: a raça miscigenada, o meio e a cultura. O elemento modificador que poderia "consertar" os outros dois seria a cultura. Por isto, o pensamento brasileiro e a sua elite letrada deveriam ser orientados de acordo com a "intuição crítica moderna", colocando o país no rumo do progresso. Neste período, entre 1865 e 1885, a sua obra sedimentou os seus alicerces, destacando-se em sua passagem no Recife pela proximidade com Tobias Barreto e pela luta contra o romantismo e a metafísica na busca pelo entendimento científico dos estudos sociais.

Palavras-chave: Sílvio Romero; Modernidade; Progresso; Raça; Cultura; Ciência.
\end{abstract}

Abstract: At the end of the Empire, a young intellectual, Silvio Romero, intended to interpret the country - and its formation - from the new philosophical vows of Europe (positivism, evolutionism, etc.), which he called "modern critical intuition". Enthusiastic about the Second Industrial Revolution and the ideologies of progress that came from outside, Romero advocated the absence of universals. Every epoch had its relative truth, and it would evolve evolutionarily toward progress. He interpreted the formation of the country from a tripod: the mixed race, the middle and the culture. The modifying element that could "fix" the other two would be culture. For this reason, Brazilian thought and its literate elite should be guided according to "modern critical intuition", putting the country on the path of progress. In this period, between 1865 and 1880, his work sedimented its foundations, standing out in its passage in Recife by the proximity with Tobias Barreto and the fight against the romanticism and the metaphysics in the search for the scientific understanding of the social studies.

Keywords: Sílvio Romero; Modernity; Progress; Human Race; Culture; Science

\footnotetext{
* Doutorando do Programa de Pós-Graduação em História (PPGHIS) da Universidade de Brasília (UnB). E-mail: elton_flaubert8@hotmail.com
} 


\section{Introdução}

O sergipano Sílvio Romero faz parte de uma nova geração intelectual, que vai surgindo no final do Império, conhecida como "geração de 1870". A construção da nação após a independência foi marcada pela centralização política e busca pela unidade e identidade nacional. Neste processo, foram se construindo também instituições de conhecimento no país, fazendo com que a elite letrada fosse formada aqui e não mais em Coimbra (CARVALHO, 1980). Conquistada a unidade nacional, faltava ampliar os espaços institucionais para os que ocupavam a margem da ordem montada no Segundo Reinado (ALONSO, 2002).

A “geração de 1870", multiforme em ideias, nasce neste contexto de desestruturação do Império, modernização, e insatisfação com as estruturas políticas e socioeconômicas. Eles se aproveitavam dos novos meios de imprensa, com jornais e revistas, do crescimento das cidades, da estabilização de um ambiente intelectual com autores e leitores, e enfrentavam a obstrução da ampliação da participação. Não há uma unidade entre estes pensadores, mas eles orbitam em torno das ideias de reforma no país (ALONSO, 2002).

Sílvio Romero faz parte de um movimento chamado por ele de "Escola do Recife". Embora não haja uma unidade doutrinal, os seus integrantes fazem parte de um grupo de sociabilidade com leituras em comum, e abordagens semelhantes, que traz ao país um "bando de ideias novas" que estavam em voga na Europa: positivismo, evolucionismo, materialismo, monismo, naturalismo, culturalismo, etc. Estes jovens acreditavam na ideia de progresso e que o país deveria ser interpretado a luz científica, e eram leitores de Comte, Darwin, Spencer, Taine, Littré, Buckle, Moleschott, entre outros.

$\mathrm{Na}$ intersecção da leitura desses autores - e do que suas ideais representavam - com o desejo de reformar cientificamente o país, encontramos uma tensão constante na obra destes intelectuais. Eles estavam divididos entre o pessimismo pelo passado colonial e o otimismo com as promessas de progresso da civilização. A ciência operatória e a orientação correta do pensamento precisavam intervir naquilo que eles chamavam de "atraso cultural" da nação ou da província. Para tal, era preciso buscar as causas deste “atraso" e propor soluções

Era 1868, um ano diferente na vida do Recife. É o marco da ruptura com o saber tradicional para Romero. Surgem no Recife diversos jornais e revistas, divulgando as novas teorias científicas, sistemas filosóficos, combatendo o clericalismo dominante. 
Sílvio Romero chegara a cidade para estudar direito, encontrando um ambiente intelectual vivo, dinâmico, ávido pelo novo, convivendo nos estudos, nas polêmicas e nas folgas com alguns daqueles que, nas décadas seguintes, iriam frequentar com sucesso as tribunas, os cargos públicos, a imprensa. Entre estas figuras, podemos destacar: Antonio Herculano de Souza Bandeira Filho, futuro diretor da Instituição Pública do Distrito Federal; Joaquim Ferreira Chaves Júnior, mais tarde governador do Rio Grande do Norte, senador e ministro da Marinha e da Justiça; além de intelectuais como Domingos Olímpio, Araripe Júnior e Capistrano de Abreu. Além do destaque das suas duas maiores figuras: Castro Alves e Tobias Barreto, que dominavam os embates intelectuais na cidade.

Neste ambiente de efervescência intelectual, Sílvio Romero iniciou sua carreira literária redigindo o jornal acadêmico A Crença. Ao longo dos anos na Faculdade de Direito viria a colaborar com poesias e artigos de crítica em diversos jornais pernambucanos, muitos deles efêmeros: O Americano, O Correio Pernambucano, $O$ Movimento, O Liberal, A República, Jornal do Recife, e o Diário de Pernambuco. Nestes textos, Romero aparece combatendo o romantismo e a metafísica religiosa do seu tempo.

\section{A luta contra a metafísica tradicional e o método crítico}

A recorrência da escrita nos jornais foi fundamental para fomentar o estilo agressivo de Sílvio e o seu gosto pelo embate e pelas polêmicas. Durante o período acadêmico, Romero concentrou seus artigos na crítica ao romantismo, e só no decorrer da década de 1870 aprofundou questões filosóficas já esboçadas. Entusiasmado com o "bando de ideias novas" vindas da civilização, Romero irá tentar adapta-las a nossa realidade, mostrando nossa originalidade e identidade, mesmo que às vezes de maneira pessimista, abrindo trilhas para os estudos sociológicos, literários e etnológicos, um campo vasto. O crítico acreditava que era preciso modernizar o país a partir da orientação de sua elite letrada, tornando-a refratária ao essencialismo metafísico e ao romantismo.

Para o jovem Romero, estudante de direito no começo da década de 1870, só teríamos uma nova literatura quando o pensamento brasileiro parasse a contemplação, despindo-se dos velhos cacoetes. Para isto, não era preciso abrir mão da figura do mestiço, do negro, ou do indígena, mas dever-se-ia coloca-los no fluxo da marcha civilizatória de algum modo. Devíamos nos apoderar das novas imaginações que iluminam a ciência moderna: "a civilização moderna é uma obra complexa, para ela todos os povos devem

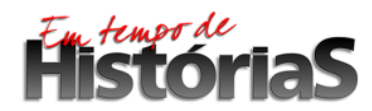


agitar-se" (ROMERO, 1880: p. 66). Para ele, seria necessário dialogar com estes novos saberes, para ler cientificamente nossa formação e, finalmente, prestar alguma contribuição à civilização. Nisto, estava embutido ideias filosóficas.

Depois de estudar a nossa literatura e constar nela um "atraso" de acordo com as vogas filosóficas que vinham de fora, Romero começou a desenvolver um método crítico e filosófico para atualizar os estudos sociais brasileiros, ajudando na construção da nação. Aqui, começa a sua luta contra metafísica tradicional. Na sua defesa de tese de doutorado, há o célebre episódio descrito na "Ata da Congregação", documentado encontrado por Clóvis Beviláqua. A confusão começa quando Sílvio Romero entra num embate com um dos julgadores, o catedrático Coelho Rodrigues. Assim, conta-se sobre o diálogo travado:

“ - Nisto não há metafísica, há logica.

- A lógica não exclui a metafísica, replicou o arguente.

- A metafísica se não sabia, o saiba, treplicou o doutorando.

- Não sabia, retruca esse.

- Pois vá estudar e aprender para saber que a metafísica está morta.

- Foi o senhor quem a matou? Perguntou-lhe então o professor.

- Foi o progresso e a civilização". (Atas FDR, 185 apud SCHWARCZ, 1995: p.194)

Romero, em seguida, se levantou, reclamando da ignorância dos integrantes de sua banca. Conta Beviláqua (2012: p.217) que, desde esse episódio, o sergipano ficou marcado na faculdade, fechando as portas para qualquer possibilidade de avanço institucional. Araripe Jr. assim descreveu o incidente e o seu impacto:

"É célebre a cena que o crítico (Romero) provocou quando, pela primeira vez, encontrou-se em tête-a-tête com a ciência oficial (...) Fora incumbido de cortar-lhe as asas no voo temeroso o Dr. Antônio Coelho Rodrigues, ex-senador federal e então uma das mais recentes e fogosas ilustrações daquela corporação. (...) $\mathrm{O}$ arguido ouviu as primeiras objeções. Não tardou porém em inflamar-se e, estranhando que professores ilustrados se ocupassem ainda com as célebres distinções entre o direito e a moral, ergueu-se. (...) Não se imagina a indignação que se levantou no espírito daquele que já ousara criticar os melhores poetas e escritores do Brasil. No decurso da discussão, que se travara mais acesa com o ilustre romanista acima citado, surgiu incidentemente a frase: "a metafísica morreu". (ARARIPE JR., 1905 apud MENDONÇA, Carlos Sussekind de, 1938: p.128-129).

Nesta época, fazia sucesso o ecletismo do francês Victor Cousin. No período da colônia, era predominante a tradição escolástica na elite letrada. A independência do país

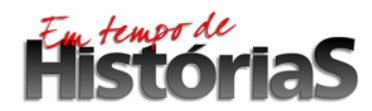

(PPGHIS/UnB) №. 32, Brasília, Jan - Jul 2018 ISSN 2316-1191 
fez crescer um desejo de pensar o país fora da influência lusitana e a partir das filosofias modernas, mas não há um predominante desejo de ruptura com o passado. $\mathrm{O}$ ecletismo significa uma transição, da nação recém-independente, com seu monarca de linha portuguesa. Ele alinhava espiritualismo metafísico com as filosofias modernas, trazendo em sua linha política, um sério desejo por algumas reformas dentro da ordem. O historicismo é introduzido no país, indiretamente, pelo ecletismo cousiano. Ele representa a consciência de esse mudar histórico, tendendo ao relativismo gnosiológico, já que o Homem não teria natureza, mas só história. Dessa maneira, seria fundamental estudar a historicidade do humano, captando com o transcorrer histórico a essência do homem em seu devir. O comportamento dos diversos fatores dependeria da história.

A filosofia seria, assim, a história dos seus problemas, uma sequência de tematizações com desdobramentos. O historicismo é uma espécie de "ecletismo dinâmico" (SALDANHA, 1986: p. 20), que problematiza a historicidade dos homens e mistura as escolas, tendo tendência contrária aos sistemas estáticos. Caberia ao filósofo distinguir em cada escola ou ideário, a parte nuclear, aproveitável, e com este entendimento situar historicamente e fazer progredir o conhecimento. É esta a base do historicismo de Romero.

Em 1878, no seu livro A Filosofia no Brasil, Romero faz uma severa crítica dos iniciadores da cultura filosófica no país, apontando sua principal lacuna: a falta de embate entre as ideias, resultando na ausência de uma genética ou tradição. As modas vão se sucedendo, e uma vai sendo largada em prol da outra, sem que haja um combate, um trabalho de síntese. Neste sentido, um autor não dialoga com o outro, e um sistema não é resultado do seu enfrentamento com um anterior. Afirma Romero:

\footnotetext{
"Na história do desenvolvimento espiritual no Brasil há uma lacuna a considerar: a falta de seriação nas ideias, a ausência de uma genética. Por outros termos; entre nós um autor não procede de outro; um sistema não é uma consequência de algum que o precedeu". (ROMERO, 1878: p. 35).
}

Disto resulta a nossa falta de tradição intelectual, que abriu mão da ideia de cadeia, ou mesmo de sistema. Esta debilidade é fruto da nossa falta de espírito público e, principalmente, da falta de espírito científico, resultado de séculos de jesuitismo na educação. Os trabalhos anteriores se tornam "filhos perdidos no torvelinho da indiferença" da geração atual. 
Romero identifica - no século XIX - três grupos de estudos filosóficos brasileiros: a) o sensualismo metafísico francês e o ecletismo francês; b) as reações católicas e metafísicas, com influência de Gioberti, Rosmini, e Ventura; c) e os "emancipados das superstições", leitores das novas ideias, que se sucedem na marcha do progresso científico, são os leitores de Comte, Darwin, Spencer. E são essas três filosofias que ele pretende analisar em seu livro, para depois oferecer um diagnóstico da renovação necessária para a cultura nacional e a filosófica.

O sergipano defendia a inexistência de verdades universais e atemporais. Para ele, só haveria uma verdade relativa - a "verdade da época" -, sucedendo-se no tempo em processo cumulativo. Ocorreria uma marcha das ideias, aonde uma iria superando a outra, gerando progresso do conhecimento e também material. E o guia para essa evolução seria a ciência e a "intuição crítica moderna". A partir da crítica do antigo, a nação poderia entrar nos rumos corretos desta marcha, estar de acordo com a verdade de seu tempo. Assim, só conhecemos o "como das coisas" e nunca o "por quê". O seu realismo materialista era assim uma teoria do conhecimento.

O seu criticismo anti-sistemático, crente da força do progresso e da marcha das ideias, era uma mistura das várias influências das ideias em voga na sua época. Toda verdade seria relativa, sendo dependente do progresso do século e da época histórica. A filosofia teria por dogma a relatividade de todas as coisas. Para Romero, a humanidade procede por evolução, e no conhecimento também. Existe uma marcha das ideias, onde não há gênios, mas só desdobramentos. E as regularidades e leis observáveis desta marcha se davam pelos choques e enfrentamentos. Na marcha das ideias, tivemos Descartes quebrando os saberes medievais, depois Hume e Locke, donde Kant retirou sua filosofia. Seguiu-se com Fichte, Schelling, Hegel, o sensualismo, Hartmann, o positivismo, o evolucionismo, o materialismo. Mesmo na arte, assim também ocorreu, com Mozart sucedendo Hayden, e depois vindo Beethoven. Cada qual expressando a verdade do seu tempo, enfrentando e superando seus antecessores.

Para Romero, foi assim que o politeísmo derrotou o fetichismo; e, depois, o monoteísmo matou o politeísmo. Com o espírito crítico, a metafísica bateu a teologia; depois, aliado ao positivismo, bateu a metafísica. O espirito crítico seria uma necessidade permanente do pensamento, uma condição fundante do movimento e da luta pela vida na esfera das ideias. A intuição crítica, junto com o monismo materialista, causaria golpes fatais contra a ortodoxia comtiana. Romero afirma que hoje a crítica deveria ter um caráter

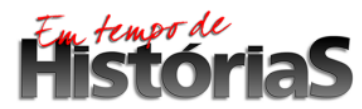


positivo, impedindo que ideias se tornassem doutrinas, sendo uma "autoridade central do pensamento". O espírito crítico representa a relatividade evolucional versus a apriorística do absoluto. Mas, não pode haver uma síntese das ciências sem uma unificação gnosiológica; por isto, Romero abre mão da metafísica, mas fica com a ontologia. Abrindo caminho para unidade dos saberes, ancorados na ciência experimental.

E para Romero, entender a marcha das ideias seria compreender o espírito do século, da vida material que se apresenta em movimento. Existe uma semelhança, para ele, entre a evolução da sociedade e das leis do espírito, com nexos causais dos processos naturais. Por isto, é possível utilizar um método das ciências na interpretação dos fatos históricos. Ele julga a história de maneira prospectiva: o espaço da evolução futura. Mas, o futuro da evolução seria ditado não só pela biologia, mas pela consciência. Nisto, consiste o papel determinante da intuição em Romero. Ela capta o espírito do século, trabalha com os fatos positivos após compreender para onde está indo, em sua marcha inexorável.

No conceito evolutivo de história tomado por Romero, as ideias se sucediam progressivamente em direção a maior liberdade do homem ao "atraso" da crença, sendo sempre renovada pela "verdade do momento", criando uma temporalização do conhecimento. E no sentido dado a história, o Brasil é analisado nesta perspectiva, trazendo junto, as ciências da época. Por estas observações acerca da ação humana e sua liberdade perante a adequação da nação a teleologia da história, o seu olhar se volta para os estudos culturais e para o Brasil, elaborando uma crítica estética e estilística de orientação nacionalista. A partir dessa base filosófica, Romero irá fazer uma abordagem histórico-cultural, tratando a literatura e o folclore, por exemplo, como documentos históricos de cultura nacional. Isto a partir de um método: o da crítica.

O método crítico pretende captar o espírito do século, através da verdade relativa que surgirá do embate com as ideias anacrônicas, mortas na marcha da evolução. A crítica ilustra o espírito da humanidade, descobre a analogia das obras no envolver do tempo. Para além do comentário, a crítica não é só uma intepretação, especializando-se no esclarecimento científico, histórico e social. E como a cultura é um sistema, ela não pode abdicar da "intuição crítica moderna” para dar-lhe uma direção esclarecida.

\section{A transformação da cultura nacional pela "intuição crítica moderna"}

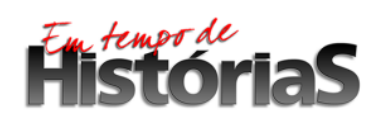

(PPGHIS/UnB) №. 32, Brasília, Jan - Jul 2018 ISSN 2316-1191 
O método crítico desenvolvido por Romero deveria servir para adequar - através do pensamento - os estudos sociais e a cultura à "intuição crítica moderna". O pensamento ligado a ciência deveria servir à construção da nação. Três elementos eram importantes na fundamentação de um povo e de uma nação: raça, meio e cultura. $O$ brasileiro seria um povo miscigenado, a partir do hibridismo entre português, negro e indígena. Entre o final da década de 1870 e começo da década de 1880, Romero acreditava que a raça e o meio seriam causas naturais do nosso atraso. Por outro lado, seriam fatos que também produziriam nossa originalidade. O terceiro fator, a cultura, ou ainda, a orientação de pensamento que a nação possui, deveria ser o fator decisivo para amenizar a perda com os outros dois. Por isto, ele se volta contra as ideias dominantes da época - como o essencialismo da metafísica e o romantismo -, por identificar neles a responsabilidade pelo "atraso" cultural. Para corrigir os nossos rumos, era preciso dar uma orientação científica ao pensamento do país a partir da "intuição crítica moderna".

Neste combate, emergia o sentimento de que o futuro desejável da nação passaria por uma reforma intelectual, uma orientação do pensamento, dirigindo-se aos símbolos modernos através da ciência hodierna e da verdade de sua época. Para além das teorias raciais e do darwinismo social, predominantes entre os progressistas da metade do Século XIX, Romero acreditava que era possível transformar o Brasil numa nação moderna, reformando sua cultura, ao dar-lhe direção na intuição moderna, diminuindo o que seriam, para ele, defeitos naturais (mas também sua originalidade) de nossa formação (como a raça e o clima).

Para o crítico sergipano, a artificialidade da cultura brasileira encontrava-se na metafísica ultrapassada pela ciência e no romantismo pitoresco e grotesco. A poesia romântica representava toda artificialidade da cultura intelectual do país, pois era falsa, tratando de símbolos inexistentes, de maneira pitoresca e não científica. A poesia romântica desandou a falar sobre os índios e a cultura popular, sem fazer um estudo científico sobre nossas lendas, nossos costumes, e nosso folclore. A ciência da crítica, ao contrário, pretende renovar o antigo terreno da filologia, das criações mitológicas e religiosas. Eis como Romero trabalha a literatura como um documento cultural.

No texto A literatura brasileira, suas relações com a portuguesa, e o neo-realismo, publicado na segunda edição de 1879 da Revista Brasileira, o crítico sergipano reafirma com esse texto a necessidade de rever nosso passado literário, com suas riquezas acumuladas, para propor mudanças. A tarefa da crítica nacional atualizada é estudar a

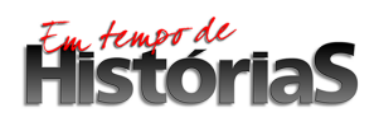


ação do meio, da raça, da tradição popular, a fim de dar orientação certa ao pensamento, por que este, bem orientado, age decisivamente sobre as instituições e o meio. A crítica é a arma do conhecimento que remove a mentalidade. É a atividade social do pensamento. A crítica literária visa refundir a ideologia do país, mediante a tomada de consciência dos problemas brasileiros, examinados a luz do pensamento científico moderno. Estudar a literatura brasileira, para Romero, significava identificar o nível de atraso mental do povo, sendo um sintoma de progresso ou atraso.

Anteriormente, em 1871, no jornal de maior circulação do Recife, o Diário de Pernambuco, Romero publicou um de seus mais importantes artigos, A Literatura Brasileira e a Crítica Nacional. Nele, o sergipano seis autores que por força da vontade ampliaram o esforço de diferenciação nacional e de progresso: Gregório de Matos, Gonzaga, Santa Rita Durão, Martins Pena, Álvares de Azevedo e Tobias Barreto. O primeiro exprime a fusão dos três povos e o despertar da consciência nacional, $\mathrm{O}$ segundo transforma o lirismo português para nossas tradições, o terceiro introduz o índio na nossa literatura; enquanto, Martins Pena por satirizar a burguesia portuguesa, Álvares de Azevedo que nos lança no espírito do cosmopolitismo moderno e de suas agruras, e Tobias Barreto que inicia a crítica à nossa realidade. Esta seria a marcha histórica dos autores com contribuições mais fundamentais para a literatura nacional, e para o estabelecimento da crítica nacional. E na figura de Tobias Barretos, teríamos a atualização mais recente.

Entre o otimismo e o pessimismo com nossa condição, Romero acreditava que era possível modernizar o país, dando-lhe uma orientação científica. E para isto, seria essencial o estudo da sociedade, da cultura, da história, da política, através dos modernos métodos da sociologia, da historiografia, da etnologia, etc. Modernizar o país significava entendê-lo por uma chave cientificista, aplicando ao estudo da sociedade brasileira os métodos das ciências naturais, trazendo-os, portanto, para as análises sociais. A sociedade passava a ser concebida como um organismo, com coerência interna, mas que reage aos incentivos externos.

Como mostra José Murilo de Carvalho (1980), no início do império a formação da classe letrada no país era voltada para burocracia e para criação do estado nacional, consolidando a soberania. Havia uma tendência bacharelesca, intelectualista, estatal, mas também, literária, onde nela todas as humanidades se abrigavam. A formação intelectual era voltada a carreira burocrática. Fernando de Azevedo (1963) sintetiza dessa forma:

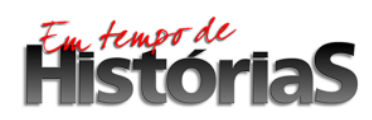


"A formação intelectual que recebiam, eminentemente literária, orientada não para a técnica e a ação, mas para o cuidado da forma, adestramento na eloquiência e o exercício das funções dialéticas do espírito, não podia fazer desses mestres em Artes e licenciados senão letrados, imitadores e eruditos, cujo maior prazer intelectual consistia no contato com os velhos autores latinos" (AZEVEDO, 1963: p. 278).

Para Romero, esta busca pelo humanismo obnubilava a coisa prática, e dificultava a entrada dos estudos científicos. Os estudos sociais seriam tomados por teorias, e não pela análise científica dos fatos positivos. Por isto, no estudo da literatura, foi além da mera descrição dos elementos nacionais ou da problematização do caráter de verdade do documento, buscando, na verdade, o sentimento do país que apresentaria nossa intuição equivocada e afastada das recém-descobertas modernas. Para, a partir disso, fazer uma reforma intelectual, moral, científica, no país. No entanto, longe da suposta objetividade do rigor científico, Romero estava mais preocupado com a dimensão política e civilizacional que o seu trabalho supostamente teria ao país. Mais do que propriamente um caráter intrínseco de verdade, apuro teórico e intelectual, que corresponderia - de fato - ao amadurecimento da cultura letrada nacional, Romero estava preocupado com suas dimensões políticas. Havia, neste desejo por alcançar o moderno, uma admiração com as ideias progressistas de fora, macaqueando-as numa inspiração crítica. O pessimismo com a formação do país encontrava refúgio numa tímida esperança em adequar nosso futuro, e com as originalidades que encontrava em seus estudos.

Deste esforço de Romero na fundação das ciências sócias entre nós, duas coisas se destacam: a) as abordagens e o material coletado que abriam caminhos para análise sociológica, b) o excesso de retórica e brava na luta contra o que era antigo ou tradicional na elite letrada, condensando uma ambiguidade mal resolvida na obra, entre deslumbre modernizador e busca por alguma originalidade nacional. Entremeados na construção teórica da sua obra, Romero empenha-se na reflexão de nossas singularidades. O que formou o Brasil? O que é o povo brasileiro? Qual o caráter do povo brasileiro? Em busca destas respostas, ele vai desbravar as disciplinas das ciências humanas, fundadas no mesmo século, desejando dar respostas objetivas, baseadas em fatos, documentos, guiados pela intuição crítica.

A partir desta chave, Romero apropria-se dos métodos da etnografia de sua época, tornando-se entre nós também um pioneiro da antropologia cultural. As suas maiores referências vieram dos livros de etnógrafos de sua época: Taine, Renan, Max Muller, 
Gubernatais, Bréal, Gobineau. Em 1875, o sergipano publica o livro Etnologia Selvagem, composto de um artigo sobre o livro de Couto Magalhães, publicado no semanário A Escola, e do artigo, o "caráter nacional”. Nele, Romero analisa a tese central de um livro de Couto Magalhães, que afirmava a existência de cruzamentos pré-históricos de nosso caboclo com alguma raça branca. Para Couto, principalmente, entre os que falavam o idioma tupi, não existindo nela vestígio do sânscrito como no quíchua, provando que a raça que lhe cruzou não foi a mesma dos incas e da América Central. Romero o elogia por romper com o misticismo indígena imposto pela literatura romântica, e pelo caráter científico do seu livro, mas contesta as teses centrais do autor, por estarem pouco de acordo com as novas metodologias científicas. O sergipano critica o fato de o índio ser visto de maneira exótica, lúdica e até grotesca pelo romantismo brasileiro, impedindo a intuição crítica e científica do tema. Assim, ele traça no início de sua argumentação uma linha crítica dos estudos indígenas até aquela época no país; que estavam em dissonância com as descobertas científicas americanas, para o qual, o índio era objeto da ciência, e não da poesia.

Estes são os principais erros de Couto anotados por Sílvio: a) multiplicidade da língua ariana, b) peruanos não só são incas, mas estes eram o cume de diversos povos peruanos, como os quíchuas, os pirhuas, e os purhuas; c) existiam muitas diferenças entre os peruanos e os povos da América Central; d) dificuldade em provar os parentescos entre a língua tupi e as línguas indo-germânicas e as semíticas (hebreus, árabes, etc.); e) não há prova de cruzamento entre arianos e peruanos. Para mostrar os erros estruturais da argumentação de Couto, Romero toma como certa sua hipótese para mostrar o nexo científico e levando as devidas consequências.

Estes nexos encontrados entre as línguas provariam apenas a "uniformidade das leis que presidiam ao desenvolvimento do espírito humano por toda parte" (ROMERO, 1875: p. 28). Para ele, através de um método fluído como o de Fidel Lopes poder-se-ia provar o parentesco de todas as línguas. O sergipano afirma que o caboclo desconhecia o bronze, o ciclo do tempo, a domesticação dos animais, e as gramáticas das línguas eram extremamente diferentes uma da outra. As semelhanças etimológicas não seriam suficientes para provar o parentesco das línguas, e consequentemente, o cruzamento das raças. Portanto, Romero descarta que o tupi tenha vindo do arianismo. Ele afirma:

"Admitidas às três grandes ramificações da linguagem, cumpre observar que elas correspondem a outras tantas ordens de ideais

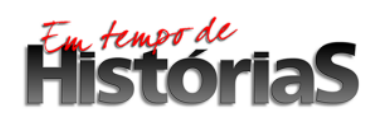

(PPGHIS/UnB) No. 32, Brasília, Jan - Jul 2018 ISSN 2316-1191 
também distintas na esfera religiosa, política, artística, econômica... A filologia não eleve esquece-lo; sempre que quiser, sem prova suficiente, aplicar a tríade asiática ao resto do mundo, no empenho de ver reproduzidas as exatidões de seus achados por lá, corre o perigo de falsificar a ciência. E' o que vai fazendo em larga escala para a América. (...) A filiação dos povos de cada um dos grupos daqueles idiomas asiático-europeus tem uma base, além da linguística, na história. Não assim na América, onde falta este elemento do moderno método". (ROMERO, 1875: p. 25).

Compreendendo não só a língua, mas outros elementos de cultura, como as ideias e as religiões, poder-se-ia classificar as tribos do Novo Mundo em grupos diferentes. Um parentesco distante que ligue estas ao velho mundo não passam de hipótese sem provas para Romero, pois ambos os povos resguardam inúmeras diferenças, não havendo provas nos fatos positivos. As semelhanças entre os povos primitivos americanos e os povos do antigo continente se deviam mais as semelhanças entre os humanos do que propriamente uma linhagem familiar. Então, qual a origem dos americanos? Eis, a pergunta que Romero tenta responder em seu texto. Ele sintetiza duas hipóteses aclamadas na ciência europeia da época: a) origem asiática, que era predominante entre os cientistas; b) e a origem própria, defendida por Buckle.

A hipótese autóctone dos habitantes que se encontravam na América na chegada dos europeus já foi amplamente desmentida pelas descobertas arqueológicas de hoje. Porém, fazia algum sentido para Romero na diferenciação de tipos humanos, incluindo nisto, outras raças. A diferença entre os "conquistadores europeus" e os povos encontrados nos novos continentes gerou a busca por uma explicação a respeito dessas diferenças. E no começo do Século XIX, havia uma disputa entre monogenistas e poligenistas na antropologia. O monogenismo tinha como hipótese o pertencimento de todas as raças (ou etnias) numa mesma espécie; descendendo, portanto, de um ancestral comum. Ou seja, todos os homens seriam uma mesma espécie, com único tronco. Já o poligenismo defendia a hipótese de que havia diferentes linhagens de raças (ou etnias) humanas, não se podendo encontrar um ancestral comum. A partir de meados do século XIX, com o predomínio do evolucionismo de Darwin, o monogenismo tornou-se inquestionável.

Os poligenistas daquela época se voltaram para outros fatores radicais de desnível entre as etnias, criaram-se então vários tipos de determinismo, como o geográfico (baseado no espaço físico, no clima, na topografia, etc.); e o racial, voltadas para supostas diferenças biológicas entre elas, e superioridade de uma raça sobre a outra. Por este 
caminho, enveredaram Buckle, Renan, Gobineau, entre outros. De certa forma, os filhos do poligenismo foram os principais responsáveis pelo racismo científico da época ou por preconceitos naturalistas, pois não haveria mobilidade entre as raças ou o meio. Romero tenta um caminho eclético entre estes grupos (ROMERO, 1875: p. 28).

Apesar de não negar o monogenismo, Romero advoga que a primazia da unidade entre alguns fatos humanos não comprova necessariamente uma origem única. Por influência tanto do evolucionismo quanto de Buckle e companhia, ele tenta integrar essa base poligenista, do meio e da raça, com os diferentes estágios de desenvolvimento das sociedades. Para Romero, a raça era um elemento preponderante para o desenvolvimento das civilizações e de suas diferenças, mas não "doutrinaria" o todo. Para dar cabo das variedades que apresenta o pensamento humano nos períodos primitivos da história seria preciso ir além do fator da raça, embora ele estivesse longe de despreza-lo. À raça, Romero acrescentava o clima e a geografia da região na formação do caráter de um povo. E junto com estes, o elemento humano de orientação do conhecimento.

E através do quadro de eras do positivismo, o índio encontra-se na primeira fase de todas as classificações, havendo elementos dissonantes e atrasados na nossa miscigenação. Porém, esse atraso poderia ser elucidativo para ciência, uma espécie de país-laboratório, demonstrando teses, avançando o conhecimento sobre atraso e progresso, e elementos determinantes na formação de um povo. Esta seria nossa contribuição. Uma espécie de otimismo numa maré de pessimismo acerca de nossa formação, legada pela ciência posta no altar.

Sílvio Romero continua a análise de Couto de Magalhães num artigo de 1876, depois publicado no livro Etnografia Brasileira, intitulado: Couto de Magalhães e a influência dos selvagens no folk-lore brasileiro. O alvo de Sílvio, desta vez, é outro livro de Couto, Os Selvagens, que se apresenta como uma união de contos dos "selvagens" (índios) brasileiros. Romero critica a "monomania" de Couto em forçar parentescos e filiações entre os povos do velho mundo e os indígenas da América. Se o livro tem como mérito chamar atenção para as origens do tupi, mas fracassa ao ser pouco científico, estudando pouco os fatos, fragmentando-os, e gerando confusão numa retórica abusiva. A grande crítica de Romero é que os indianistas brasileiros não estudam as origens portuguesas e os negros, ficando restritos ao campo de observação dos indígenas. Isto impossibilitaria o olhar científico, ainda mais porque, para o crítico, o africano possuiria

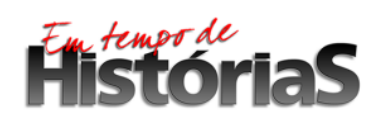


ainda mais força do que o índio para modificar o português, sendo um elemento mais vibrante na miscigenação.

Após analisar os contos apresentados por Couto de Magalhães, diz Romero no final do artigo: "O povo mudou o símbolo da destreza indiana, o veado, por um animal mais seu conhecido - o bode. Assim vai se operando por uma raça a assimilação dos contos de outra. É o que se dá na língua e em tudo mais”. (1876: p. 63). Romero demonstra interesse pelo efeito cultural causado pela miscigenação, ocasionando uma cultura híbrida. Ele pretende explorar essa criatividade para dar cabo ao seu projeto científico original. Há durante todo o texto também uma tensão entre a simpatia pela causa abolicionista, e pela incorporação do negro na interpretação da nacionalidade brasileira; em relação à adoção de teorias que tinham a superioridade da cultura branca como normatividade.

Seja como for, fica apresentada uma espécie de doutrina étnica brasileira, com as leis do nosso desenvolvimento espiritual, a partir do hibridismo entre português, negro e indígena, além de outras culturas periféricas. Romero critica os estudos de Wolf por só destacar os europeus na nossa formação, o que impediria a visualização de nossas peculiaridades.

Assim, Sílvio inaugura como intepretação do pensamento brasileiro, a linha que tinha por base a crítica naturalista. É nesta época, a partir da década de 70 do Século XIX, que chega ao Brasil este paradigma científico e, junto com ele, modelos de análise baseada no desvelamento entre as raças. Com o abolicionismo, vemos a construção de teorias raciais vindas da Europa a partir de uma importante pergunta: qual o espaço da nação, um país mestiço, frente ao Ocidente e as ideias de predominância raciais (que não eram hegemônicas no velho continente, mas tomava conta do ideário progressista)? Tendo em vista que, junto com a modernização econômica do Império, veio também os símbolos de modernidade.

As teorias raciais que colocavam na mistura racial a culpa por nosso atraso diante da Europa eram bastante influentes nos debates públicos brasileiros, e podem ser vistos no Parlamento, nos livros, nos jornais. Estas teorias chegaram a ter mais influência na periferia do mundo moderno do que no velho continente, onde sempre foram combatidas por um número razoável de pessoas dentro da cultura letrada.

Orbitando entre evolucionismo e determinismo, Romero concordava com a influência do fator racial e geográfico, mas incluía nestas uma orientação de pensamento que poderia contribuir para o desenvolvimento da nação. E esta orientação encontrava-

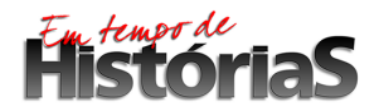


se, por influência do evolucionismo, na "intuição crítica moderna". O país deveria modernizar o seu pensamento, corrigir seus eixos orientadores, olhando para a verdade do momento, almejando estar no ponto mais alto da evolução histórica. E sem negar e ser pessimista com nossa construção inferior pelo clima e pelo misticismo racial, Romero ambiguamente - procurou também visualizar o lado positivo de nosso legado, querendolhe dar uma orientação moderna. Então, ele combina estas teorias raciais com outros métodos sociológicos; evolucionismo, monismo e determinismo naturalista com culturalismo e historicismo. E isto tudo, mesmo com tantas reclamações, sem romper com aquela tradição bacharelesca e verborrágica nacional, de muita figura de linguagem, e pouca realidade.

Ao analisar a formação do país e os quatro séculos de escravidão, ele acredita que há sobre a miséria do nosso pensamento, não só o efeito da ação do meio físico, mas por outros efeitos culturais, até em relação à alimentação. O ímpeto moderno, criador e crítico, poderia reformar a cultura brasileira, e dar-lhe ar moderno. A modificação da nação viria numa equação entre meio e intelecto, onde este poderia modificar o meio, e dar-lhe um terreno propício. O meio seria os aspectos físicos do país (clima, topografia, etc.) e as suas raças constituintes. E o intelecto seriam as ideias predominantes e ordenadoras da ação humana. Estas ideias se estivessem de acordo com a verdade de sua época, poderiam determinar o meio. Ou seja, determinadas ideias, direcionadas ao progresso evolutivo, poderiam agir sobre o meio determinado. Sendo assim, há uma composição entre meio físico, raça, e momento espiritual do país. E o escritor deveria encontrar-se neste encontro entre momento social do país e do mundo na escala evolutiva, como sua ideologia.

Este talvez seja um dos aspectos mais importantes e sintomáticos da obra em formação de Sílvio Romero, a importância dada por ele às essas novas ideias, como papel da ideologia que deve formar um país. Ele enxergava isto como uma verdade momentânea, um espírito da época que se dirige ao progresso de mais liberdade do espírito humano, a tal ponto que este conjunto de ideias pode modificar o meio, a raça, e outros aspectos determinantes em sua análise. A ideologia do escritor é alçada a um patamar decisivo do transcorrer histórico. De tal modo que o nascimento destes estudos sociais científicos já vem do berço com a ação de uma doutrina coerente de ideias, mesmo ela sendo materialista ou culturalista, relativizando sua verdade no tempo.

\section{Filistorias}


E a ação da ideologia nos estudos culturais das ciências humanas deveria ser guiada pelo método crítico, que irá combinar a ação do clima sobre a população, a formação e origem racial, o folclore e sua gênese, e o hibridismo cultural. A feitura do "caráter" nacional é uma síntese de cultura, e não apenas uma determinação racial ou geográfica. Sendo uma relação entre o mistiscismo racial, as condições do meio geográfico, e a estética e orientação das obras que norteiam o pensamento nacional.

Escrito em 1873, e publicado no Diário de Pernambuco, o artigo O caráter nacional e as origens do povo brasileiro é uma síntese de Romero a respeito da formação do nosso povo. Preliminarmente, ele afirma que dois fatores podem pesar na feitura de um caráter nacional: a natureza e a aglomeração de populações distintas.

Assim, os povos se modificam pela natureza que os cerca, depois de muitos séculos, e também através da orientação dada a um grupo culturalmente heterogêneo que se une. Por outro modo, as várias aglomerações podem desenvolver-se de maneira diferente de acordo com o ambiente. Portanto, há uma ambiguidade dialética entre estas duas proposições. Um exemplo dado pelo escritor são os Arias, que se desenvolveram diferentemente de acordo com cada ambiente e população que se agrupava.

No caso brasileiro, Romero afirma que "somos um povo moderno oriundos de outro também comparativamente novo e civilizado". (ROMERO, 1875: p.40). Ele diz que os portugueses trouxeram a língua, a religião, as instituições duradouras, e os costumes polidos. Mas, a formação do povo brasileiro se dá no trabalho de labor entre o português, o negro, e o índio.

Embora, a natureza ainda não tivesse força para modificar o sentido português, a diversidade da população aglomerada faria este trabalho de acomodação do hibridismo cultural. Romero critica os trabalhos historiográficos que não abordam o negro, e aqueles que abordam no índio apenas o seu aspecto estéril e errôneo.

Neste sentido, Romero põe-se contrário aos estudos da historiografia nascente por deificar o português em detrimento de indígenas e negros ou por dar mais importância ao índio do que ao negro na formação do caráter nacional. Os índios eram primitivos e pequenos, estavam no estado de selvageria, não tinham tanta força para influenciar e modificar a civilização trazida pelos portugueses, como os negros africanos. A forte derrocada indígena provaria isto.

Em especial, Romero dava importância ao estudo da língua nacional. Para ele, o fato da língua predominante ser a portuguesa, demonstrava a centralidade deste elemento

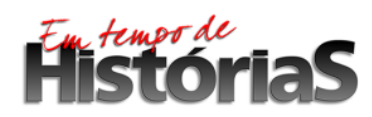


na formação do país. Mas, as diferenças práticas do português falado no Brasil do que português falado em Portugal demonstrava a mistura de nossa cultura. Os africanos tiveram, para ele, mais vigor do que os índios para alterar a língua, com seus costumes e hábitos. Por isto, o elemento africano seria mais influente em nosso caráter, apesar dos historiadores da época não perceberem. Então, qual seria o caráter do país? Para Romero, o Brasil era uma junção híbrida entre portugueses ruins, negros e indígenas.

Como o fator racial ainda era um determinante de nossa formação para o sergipano, havia em sua obra um tom claramente racista. Afirmando a superioridade biológica dos brancos, o crítico afirma que este hibridismo alterou sem vantagem nossa composição: “o africano, rebelde aos progressos intelectuais, tem alterado, sem vantagem, nossa fisionomia pretérita”. (1875: p. 46). Não deixa de ser interessante que, ao mesmo tempo, quando se trata da elite letrada e da construção das ciências no país, ele recorra de maneira muito mais otimista ao elemento negro em nossa cultura contra o atraso do saber português. Não renegava do colonizar a civilização, mas afirmava que os traços originais do país deveriam vir do hibridismo, e a partir dele, entrar na "intuição crítica moderna". Porém, o negro teria sido mais importante do que o elemento indígena na composição racial, por oferecer um fator "robusto e civilizador" que ajudou aos mestiços a se adaptarem ao clima.

Com o passar do tempo, o tom racista será abrandado. Isto se deve a maior influência do evolucionismo e do monogenismo durante sua obra intelectual: "Não deve haver aí vencidos e vencedores; o mestiço consagrou as raças e a vitória deve ser assim de todas as três" (ROMERO, 2002: p. 116). Ele sempre colocou na mestiçagem uma característica essencial para a construção cultural do Brasil, e o seu pensamento sempre se ordenou a partir disto. Sua obra sempre fluirá a partir dessa ambiguidade, nunca cessando, mas mudando sua intensidade por tempos. No início do século XX, sua obra voltará a adotar um tom mais racista, por exemplo.

Consiste numa originalidade da obra de Romero o resgate do negro perante a tradição literária brasileira, e a redefinição da mestiçagem (menos pessimista) perante as teses cientificistas da Europa. A miscigenação aparece como uma fatalidade nacional, que agora precisaria ser trabalhada e orientada. E o elemento negro seria o mais destacado dentro de nosso potencial mestiço. Uma inovação para época onde o negro era escanteado em prol do indianismo nacionalista e idealizado. Nos museus, a ciência nascente

\section{Filstortorias}


interessa-se bem mais pelos indígenas, influenciado pelas expedições científicas estrangeiras, que traziam a influência da antropologia e etnologia europeia.

Um dos embates de Romero com Celso de Magalhães era por este renegar o papel do negro na cultura brasileira, coube ao crítico sergipano o pioneirismo na importância dada a este elemento. Mas, Romero não desmente a tese do branqueamento da população, dominante nos anos 1880, acreditando que, em mais ou menos tempo, restará no país os brancos e os mestiços. Os negros tendem a diminuir sua presença devido às questões genéticas e de adaptação ao meio.

O debate em torno dessas ideias se amplia, e ação política em torno da abolição da escravatura também. Mais uma prova da relação entre o que se pensa, como se age, e a condensação disso num símbolo revelador de seu tempo. $\mathrm{O}$ abolicionismo nasceu no caldeirão de ideias da geração de 1870 e ocaso do Império. Havia, porém, muitas discordâncias internas, inclusive quantos aos meios e velocidade dessa transição. Joaquim Nabuco representava a voz dos abolicionistas moderados, que apostavam em reformas, na mobilização da opinião não-parlamentar, e nos fatores morais e anacrônicos daquela instituição. Enquanto outros abolicionistas, mais sensíveis as vogas cientificistas da época, falavam até num triunfo gradativo do branco após o fim da escravidão. A abolição e a imigração europeia ajudariam a branquear o país.

Neste sentido, o historiador Thomas Skidmore (1976) classifica Romero como um "nacionalista frustrado". Se, por um lado, era promulgador das teorias cientificistas, que não eram confortáveis quanto ao futuro da nação mestiça; por outro, era otimista quanto à possibilidade da elite letrada apreender tais doutrinas e orientar seu pensamento e ação a partir dele, modificando o país no que era possível através da cultura. Por isto, havia uma variação de humor, ora mais otimista, ora mais pessimista, nunca alcançando seu ideal. A pena da melancolia se abatia sobre o crítico sergipano sem nem perceber.

Em síntese, Sílvio vai além da mera análise determinista, seja da raça ou do meio climático, mas faz uma junção entre a população em seu aspecto racial interagindo com o meio geográfico e a orientação geral de sua cultura a partir da elite letrada. Romero estendeu o critério etnográfico, que dizia ter introduzido entre nós às explicações sociais na busca de compreender o verdadeiro Brasil, o que tanto motivou sua vasta produção literária, dentro de uma orientação ambígua e direcionada as filosofias do progresso.

\section{Conclusão}

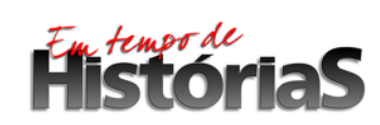


$\mathrm{Na}$ inadequação ao legado das gerações passadas, Romero buscava como compensação a mudança perpétua da "cultura do repúdio", a caricatura da ciência hodierna, as ideologias do progresso. Na crítica dura, exaltada, repleta de adjetivos contra adversários ou "advogados" do saber antigo, havia também um mecanismo compensatório contra a falta de presença, a marginalidade, o querer o que não se tem, sempre e incansavelmente.

A elite letrada contava com os meios políticos e com os meios de difusão de suas ideias. E utilizavam a mediação para dar vazão à insatisfação perene com o legado das gerações de outrora. Por sua formação e meios de ação encontram-se sempre um passo a frente da população, não vindo de sua organicidade, mas lhe tirando o ânimo verdadeiro. O pensamento de Romero, como um representante de uma vertente da "geração de 1870", condensa - em seus extremos - algumas dessas características que circulam e dominam o ambiente futuro da proclamação da República; porém, não reduz a atuação da elite letrada e de alguns intelectuais a isto.

Reler este momento é fundamental para entender o crítico e intelectual na feitura de sua obra, e compreender este mosaico fundado entre os fatos humanos e o imaginário. Pois, não só de ações e criatividade foi feito o homem; mas este, também, foi estruturado pelas intensas modificações porque passava o mundo, o país no mundo, e sua região no país.

A obra de um escritor pode nos suscitar todas essas questões. Romero não era um filósofo de brilho, nem um ensaísta de primeira (abusava de repetições, caricaturas e adjetivos), mas condensou em seus escritos: retratos de uma época e símbolos da elite letrada nacional. E na parte pungente de sua obra, os estudos de poesia popular e folclore e a coleta de material sociológico e historiográfico, abriu caminho as novas ciências das humanidades e para o estudo nacional. A partir de sua base filosófica, Romero condensava as ideias de seu tempo, baseados no conceito de progresso, evolução, e no primado do sujeito; sendo que, a partir disto, elabora uma leitura original da cultura brasileira, clamando por soluções para nossas debilidades letradas.

Todavia, as contradições afloravam na obra de Romero. Variando entre o otimismo e o pessimismo quanto ao futuro da nação, desprezava nossas tradições coloniais e a elite intelectual da corte, ao mesmo tempo em que, ia buscar no passado as manifestações culturais de formação do nosso povo, coletando poesias, cantos, danças, etc. Essa 
imbricação entre culto ao antigo ou ao moderno, também se manifestava no seu estilo: pretensamente científico e anti-bacharelesco, mas que guardava adjetivações, abusos retóricos, mania citatória, argumentos de autoridade, idealizações da rigidez científica. As ideias em marcha iam se esvoaçando. A idealização da correção científica e da verdade da sua época morria na própria relatividade de seu método de conhecimento e exposição.

Sua obra é repleta de ambiguidades, como o tempo em que viveu que era nevrálgico na formação da jovem nação e de sua elite letrada. Lê-lo como um símbolo compacto nos apresenta não só um retrato da época em diversas camadas, mas também a orientação dada por ele ao pensamento, no momento mesmo de formação das ciências sociais no Brasil. Revelando-nos a configuração dessa elite letrada que nasce, e as abordagens e problemas que ficam nos estudos sociais e históricos no país, que tanto irão influenciar as próximas gerações.

\section{Referências Bibliográficas}

ALONSO, Ângela. Ideias em Movimento. $2^{\mathrm{a}}$ edição, São Paulo: Paz e Terra, 2002.

AZEVEDO, Fernando de. A cultura brasileira: introdução ao estudo da cultura no Brasil. $4^{\mathrm{a}}$ edição, São Paulo: UNB, 1963.

BEVILÁQUA, Clóvis. História da Faculdade de Direito do Recife. $3^{\mathrm{a}}$ edição, Recife: Ed. UFPE, 2012.

CÂNDIDO, Antônio. O Método Crítico de Sílvio Romero. $4^{\mathrm{a}}$ edição, São Paulo: Ed. Ouro Sobre Azul, 2006.

CARVALHO, José Murilo de. A Construção da Ordem. $1^{a}$ edição, Rio de Janeiro: Ed. Campus, 1980.

MENDONÇA, Carlos Sussekind de. Sílvio Romero; sua formação intelectual 1851 - $1880.1^{\mathrm{a}}$ edição, São Paulo: Companhia Editora Nacional, 1938.

PAIM, Antônio. A Escola do Recife. $2^{\mathrm{a}}$ edição, Londrina: Ed. UEL, 1977.

ROMERO, Sílvio. Etnologia selvagem; estudo sobre a memória "Região e raças selvagens do Brasil". Disponível em: <http://www.brasiliana.usp.br/bbd/handle/ 1918/02054100\#page/1/mode/1up>. Acesso em: 10 de abril de 2018.

Zeitung, 1878. . A filosofia no Brasil: ensaio crítico. $1^{\mathrm{a}}$ edição. Porto Alegre: Tipografia de Deutsche

Estudos de Literatura Contemporânea. $1^{\text {a }}$ edição, São Paulo: Imago, 2002.

A literatura brasileira e a crítica moderna. $1^{\mathrm{a}}$ edição. Rio de Janeiro: Imp. Industrial de João Paulo Ferreira Dias, 1880.

A Função da Crítica. 1980. Disponível em: <http://www.casadobruxo.com.br/poesia/s/silv ior01.htm>. Acesso em: 10 de abril de 2018.

Etnografia Brasileira. Disponível em: <https://www.literaturabrasileira. ufsc.br/documentos/?action=midias\&id=143252>. Acesso em: 10 de abril de 2018 .

SALDANHA, Nélson. Historicismo e Culturalismo. $1^{\text {a }}$ edição, Recife: Fundarpe, 1986.

SCHWARCZ, Lilia Moritz. O Espetáculo das Raças: cientistas, instituições e questão racial no Brasil. $2^{\mathrm{a}}$ edição, São Paulo: Companhia das Letras, 1995.

SKIDMORE, Thomas. Preto no Branco. $1^{\text {a }}$ edição, São Paulo: Paz e Terra, 1976.

\section{Filstortias}


SOUZA, João Mendonça de. Sílvio Romero: o crítico e o polemista. $2^{\mathrm{a}}$ edição, Emebé Editora: Rio de Janeiro, 1976.

\section{Finstónerias}

(PPGHIS/UnB) №. 32, Brasília, Jan - Jul 2018 ISSN 2316-1191 